\title{
Potential and Carrying Capacity Study to Support Sustainable Tourism Development: The Case of Wedi Ireng Beach, Indonesia
}

\author{
Yuswanti Ariani ${ }^{1}$, Nailul Insani ${ }^{2}$, Hanum Rosyida ${ }^{3}$, Putri Kusuma Sanjiwani ${ }^{4}$ \\ $\left\{\right.$ nailul.insani@fis.um.ac.id $\left.{ }^{2}\right\}$ \\ ${ }^{1,2,3}$ Geography Departement, Universitas Negeri malang, Indonesia \\ ${ }^{4}$ Tourism Destination, Universitas Udayana, Indonesia
}

\begin{abstract}
Wedi Ireng is one of the beaches in the southern part of Banyuwangi Regency, East Java. This tourism object attraction offers unique beach views in the bay area with white sand and black rocks on the other side. As social media develops and promotion of tourism objects with mass media, the number of people that came to the beach is increasing day by day. Increasing the number of tourist visits is a blessing as well as a challenge in realizing the development of sustainable tourism. It is necessary to study the potential and carrying capacity of the environment so that existing tourism activities do not disrupt the ecosystem and the comfort of tourists. The purpose of this study is to identify potential tourist attraction objects and identify the value of the carrying capacity of the Wedi Ireng tourism area. The method used is based on the guidelines of the Operational Area - Objects Analysis and Attractions of Natural Tourism by The General Directorate for Natural Conservation and Forest Protection (PHKA) (2003) and assessment of carrying capacity [1]. Data collection is done through field observations, surveys, literature studies, and interviews. The results showed that Wedi Ireng Beach had value $69,5 \%$ it is means potential and deserve to be developed. Results of estimation of Carrying Capacity 454 people/ day. This value is still in the safe category because the number of tourist visits in Wedi Ireng Beach in one day ranges from 40-110 people per day.
\end{abstract}

Keywords: sustainable tourism, carrying capacity, tourism potential.

\section{Introduction}

Along with the development of tourism promotion, especially in social media, foreign tourist arrivals to East Java have increased every year. The number of foreign tourists visiting East Java experienced an increase of $12.06 \%$ from the previous year [2]. One of the cities districts that is the tourism destination in East Java is Banyuwangi Regency. Banyuwangi Regency is located in the easternmost part of East Java Province or on the eastern end of Java Island. The land area consists of highlands in the form of mountains which are the area producing plantation products; and lowland with a variety of potential agricultural products and the area around the coastline that extends from north to south which is a producing area of various marine biota. Its territory consists of 10 islands [3]. The geographical conditions of Banyuwangi Regency as diverse as this allow Banyuwangi to have considerable tourism potential, including natural tourism, artificial tourism and cultural tourism. The location of the 
existing tourist objects is spread in almost all districts in Banyuwangi Regency and make these tourism objects as assets for each region that needs to be developed.

Since 2008 the tourism sector of Banyuwangi Regency has been designated as one of the leading sectors. The Banyuwangi Regency Government chooses the concept for tourism development, especially in ecotourism in the tourism sector development strategy or offers the nature as it is in the hope that it can target the nature, cultural, and adventure tourists segment. The strategy or concept of tourism development is considered very suitable and relevant if applied in Banyuwangi Regency, considering the characteristics of the area which has a large area of plantations and rice fields and supported by many coastal areas extending from north to south will make the concept or strategy run smoothly. The existence of tourist attraction objects which can increase the welfare of the community if it is managed properly. Tourism can be relied on to improve community welfare and national development [4].

Furthermore, nature-based tourism is proliferating among tourists, because of the increasing awareness of the importance of nature for human survival. Nature-based tourism is a tourism activity in which interactions and linkages between human activities and the natural environment occur both directly and indirectly[5]. The existing ecotourism development in Banyuwangi Regency is appropriate in supporting the concept of sustainable tourism. Sustainable tourism development has a fundamental principle to guarantee the fulfilment of the needs of the present generation without reducing the ability of future generations to meet their own needs [6]. The basic principles of Sustainable Tourism is optimization on utilizing environmental resources while maintaining the ecology and conservation, respect for cultural authenticity and communities and ensure the long term sustainability [7].

According to Pitana (2009) [8], Indonesia, as a country that has the wealth of natural resources, especially the coast, has become an alternative for foreign tourists to release their saturation of modern needs. During this time the object of natural tourism attraction based on Banyuwangi Regency which is popular among foreign tourists is Ijen Crater, even though Banyuwangi Regency's leading tourist destination is not only that. The region also offers many other tourist destinations such as beaches, traditional villages, natural and artificial landscape tours, as well as cultural tourism. Natural attractions in the form of beaches, especially many scattered in several districts along the south and east coasts of Banyuwangi Regency and have a long coastline reaching $175.8 \mathrm{~km}$.

Coastal development as ecotourism is an environment that provides the resources needed to provide benefits to inner satisfaction involving certain aesthetic values [9]. As an attempt to preserve the nature, sustainability activities in tourism sector is needed, which is called sustainability tourism. Sustainability tourism will balance the positive and negative impact on tourism activities [10].

Wedi Ireng is one of the beaches in the southern part of Banyuwangi Regency, East Java. This tourist attraction is located in Pancer Hamlet, Sumberagung Village, Pesanggaran Subdistrict, Banyuwangi Regency. This makes the Wedi Ireng beach an additional or alternative tourist destination for tourists who initially only intend to go to Red Island Beach or Mustika Beach only. Wedi Ireng Beach is a beautiful small beach compared to other beaches around it, but this beach offers unique views in the bay area with white sand and black rocks on the other side. Increasing the number of tourist visits is a blessing as well as a challenge in realizing the development of sustainable tourism It is necessary to study about the potential and environmental carrying capacity, how to minimize disruption of the ecosystem and the tourism existing activities still comfort. The ability of the environment to support human life, other living creatures, and the balance of both is called the environmental carrying capacity. Environmental carrying capacity studies are very crucial to be conducted. These 
studies are preventive precaution measures to avoid environmental destruction [11]. The aims of this researchs are identifying potential tourist attractions, and calculating the carrying capacity of Wedi Ireng Beach tourism area towards tourism development.

\section{Research Method}

This research was conducted at Wedi Ireng Beach located in Pancer Hamlet, Sumberagung Village, Pesanggaran Subdistrict, Banyuwangi Regency. The location of this beach is in the south of Banyuwangi Regency, approximately $3 \mathrm{~km}$ from the Pulau Merah beach, or around $65 \mathrm{Km}$ from the centre of Banyuwangi City. Data collection techniques in this study include observation, measurement, field surveys and interviews of related stakeholders. This interview technique, in addition to a structured questionnaire, can also develop questions to explore information in more depth adjusted to interviews in the field [12].

Furthermore, the data is processed using the Operational Area Analysis guidelines Objects and Attractions of Natural Tourism (ADO-ODTWA) The General Directorate for Natural Conservation and Forest Protection (PHKA) (2003) and assessement of Carrying Capacity [1]. ADO-ODTWA method have components that are assessed, namely 1) attraction of attractions, 2) accessibility, 3) socio-economic environment conditions, 4) accommodation, 5 ) facilities and infrastructure, 6) availability of clean water. The number of values for each criterion can be calculated by the formula:

$$
\mathbf{S}=\mathbf{N} \times \mathbf{B}
$$

\section{Information:}

$\mathrm{S}=$ Score a criterion

$\mathrm{N}=$ The number of elements in the criteria

$\mathrm{B}=$ value weight

The results of the assessment of each element of each tourism object criterion are averaged so that the final assessment of the development of tourism objects is obtained and a comparison is made with the classification of development elements based on the weight value can be seen in Table 1 .

Table 1 Classification of Development Elements by Weight Value

\begin{tabular}{ccl} 
& Table 1 Classification of Development Elements by Weight Value \\
\hline No & Total Value & Assessment of Element Potential \\
\hline 1 & $660-879$ & Potential to be developed \\
2 & $480-659$ & Potential is quite feasible to develop \\
3 & $281-479$ & Potential is not feasible to develop \\
\hline
\end{tabular}

Carrying Capacity is the maximum number of visitors who can physically be accommodated in the area provided at certain times without causing disturbance to nature and humans. The carrying capacity calculation uses the following formula [13]).

$$
\mathrm{DDK}=\mathrm{K} \times \mathrm{Lp} / \mathrm{Lt} \times \mathrm{Wt} / \mathrm{Wp}
$$

Keterangan :

DDK = Regional carrying capacity (people / day) 
$\mathrm{K}=$ Ecological potential of visitors per unit area (people per $\mathrm{m}^{2}$ )

$\mathrm{Lp} \quad=$ Area or length of area that can be utilized $\left(\mathrm{m}^{2}\right)$

$\mathrm{Lt}=$ Unit area for certain categories $\left(\mathrm{m}^{2}\right)$

$\mathrm{Wt}=$ Time provided by the area for tourism activities in one day (hours)

$\mathrm{Wp} \quad=$ Time spent by visitors for each particular activity (hours)

Table 2. Ecological potential of visitors (K), area of activity (Lt), time of visit (Wp) and time provided by attractions $(\mathrm{Wt})$

\begin{tabular}{llllll}
\hline No & Kind of Activities & $\begin{array}{l}\text { K } \\
\text { visitor })\end{array}$ & $\begin{array}{l}\left(\sum \text { Unit area }\right. \\
(\mathbf{L t})\end{array}$ & $\begin{array}{l}\text { Time needed } \\
\text { Wp (hours) }\end{array}$ & $\begin{array}{l}\text { Total time of } \\
\text { 1 day } \\
\text { Wt (hours) }\end{array}$ \\
\hline 1. & Diving & 2 & $2000 \mathrm{~m}^{2}$ & 2 & 8 \\
\hline 2. & Snorkeling & 1 & $500 \mathrm{~m}^{2}$ & 3 & 6 \\
\hline 3. & Seagrass Tourism & 1 & $250 \mathrm{~m}^{2}$ & 2 & 4 \\
\hline 4. & Mangrove tourism & 1 & $50 \mathrm{~m}^{2}$ & 2 & 6 \\
\hline 5. & Recreation & 1 & $50 \mathrm{~m}^{2}$ & 3 & 4 \\
\hline 6. & Sport Tourism & 1 & $50 \mathrm{~m}^{2}$ & 2 & 6 \\
\hline
\end{tabular}

\section{Results and Discussion}

\subsection{Analysis of Potential Objects of Tourist Attraction (ODTWA)}

Data analysis used guidelines for the Analysis of Natural Tourism Objects and Interest Areas (ADO-ODTWA) The General Directorate for Natural Conservation and Forest Protection [1]. Components assessed were 1) Attraction attraction, 2) Accessibility, 3) Socioeconomic environmental conditions, 4) Accommodation, 5) Facilities and infrastructure, 6) Availability of clean water. Objects and attractions that have been assessed are then analyzed according to the 2003 ADO-ODTWA scoring criteria in accordance with the values specified for each criterion. The number of values for each criterion is calculated by the formula $\mathrm{S}=\mathrm{N}$ $\mathrm{x}$ B.

Table 3. Results of Assessment of Wedi Ireng Beach Development Elements

\begin{tabular}{|c|c|c|c|c|c|c|c|}
\hline No & Criteria & Quality & Value & Score & $\begin{array}{l}\text { Score } \\
\text { Max }\end{array}$ & $\begin{array}{l}\text { Index } \\
(\%)\end{array}$ & Information \\
\hline 1. & Atractiveness & 6 & 140 & 840 & 1080 & 77,78 & Feasible \\
\hline 2. & Accesssibility & 5 & 65 & 325 & 700 & 46,42 & Not feasible \\
\hline 3. & $\begin{array}{l}\text { Conditions Around the } \\
\text { Area }\end{array}$ & 5 & 125 & 625 & 900 & 69,44 & feasible \\
\hline 4. & Accomodation & 3 & 15 & 45 & 90 & 50 & Not feasible \\
\hline 5. & $\begin{array}{ll}\text { Facilities } & \& \\
\text { Infrastructure } & \\
\end{array}$ & 3 & 80 & 240 & 300 & 80 & Feasible \\
\hline 6. & $\begin{array}{l}\text { Availability of Clean } \\
\text { Water }\end{array}$ & 6 & 140 & 840 & 900 & 93,33 & Feasible \\
\hline
\end{tabular}




\begin{tabular}{lllll}
\hline Eligibility & 2705 & 3970 & 69,5 & $\begin{array}{l}\text { Potential } \\
\text { and Decent } \\
\text { to } \\
\text { developed }\end{array}$ \\
\hline
\end{tabular}

According to the table, the result of the assessment of Wedi Ireng Beach development elements as a whole the feasibility level of Wedi Ireng beach has a value of 695 which means it is potential and feasible to be developed as tourist attraction object. Scores for attractiveness get 840 with a feasibility index value of $77.78 \%$ which means the power of dance on this beach is worthy to be developed with consideration of the diversity and uniqueness of the resources owned. Accessibility on this beach has a score of 325 with a feasibility value of $46.42 \%$ which means it is not feasible to develop. Conditions around the area get a score of 625 and a feasibility index of $69.44 \%$ which means it is worthy to be developed. The accommodation element gets a score of 45 with a feasibility value of $50 \%$, which means it is not feasible to develop. Facilities and infrastructure have a score of 240 with a feasibility value of $80 \%$, meaning that it is feasible to develop as well as the element of availability of clean water that gets a score of 840 with a feasibility value of $93.33 \%$.

Explanation of the elements in this study will be described as follows:

a. Attractiveness

Tourist objects and attractions are all things that have a uniqueness, beauty, and value in the form of diversity of natural wealth, culture, and man-made products that are the target or destination of tourist visits [14]. The natural beauty of Wedi Ireng Beach has a value of 30 in the sense that fulfilling all sub-elements, namely on this beach, has a loose view and a variety of views in the form of growing forests in the hills surrounding the beach, there are several small islands, and white sand mixed with black sand colors with clear blue water. The colour harmony between white sand and blue sea water makes this beach unique when compared to some beaches which are also located on the same line and some gazebo buildings made of bamboo add to the natural impression.

The uniqueness and abundance of natural resources that stand out on this beach include clear blue water and sand that has unique white sand mixed with black sand. In addition, the small islands in front of the beach are unique to be enjoyed by tourists. Various kinds of forest plants that surround the beach area can also be used to shelter and add to the naturalness of this beach. Variations in activities that tourists can do include diving and swimming, but this beach does not provide services or equipment for these activities so further development is needed.

The location of Wedi Ireng Beach is 20 or moderate. This beach is protected from household waste and factory pollution because it is far from residential areas and the absence of industry in the coastal area, besides that the noise level caused by motorized vehicles is almost non-existent which adds to the comfort of tourists. This coastal area security has a moderate value where there are no dangerous sites, thefts and fires. But there are some wild animals in the forest and there are dangerous currents in a $100 \mathrm{~m}$ people to the beach is increase radius from the shoreline

b. Accessibility

Accessibility is assessed from the condition and distance of the road from the centre of the district or city. High accessibility can be created with the availability of infrastructure (road 
network) which good and supported by the availability of facilities or facilities to make a move.

This high accessibility can also be measured based on the distance of locations to city centers .

public services that are spatially identical to the city center.The distance from Wedi Ireng Beach from the district centre is $\pm 75 \mathrm{~km}$ with a travel time of 2-2.5 "with Mustika Beach destination point being the access to Wedi Ireng. The type of road is a width of more than 3 meters asphalt but when it enters Pancer Hamlet the road conditions are damaged because there are gold mining activities in the area. Until this research was carried out the main access that could be passed by motorbikes and tourist cars was not yet available to go directly to Wedi Ireng Beach

There are two routes that can be taken by tourists to go to Wedi Ireng Beach, the first is walking through the forest with \pm 30 minutes travel time and for tourists who have never crossed the route, they need the help of a local guide so as not to get lost. The second route can use a boat provided by local fishermen with a travel time of \pm 15 minutes and a fee of IDR 50,000 person commuting. Unfortunately, the boat unprovided adequate facilities such as the lack of life vest considering the path to the Wedi Ireng beach have quite large waves and coral rocks scattered on the edge of the island. Therefore it is necessary to develop to increase the standard of boat by ensuring the safety of tourists, besides that the main route needs to be built to make it easier for tourists to reach these attractions.

\section{c. Conditions Around the Area}

The results of the assessment indicate that the conditions around the Wedi Ireng Beach area have a high enough score of 625 with a feasibility index to be developed. This coastal area has fertile land evidenced by the many types of trees that can grow around the coast, but the visitors' space has a low value with an area of less than 30 ha while the highest value for a tourist area is more than 50 ha. This is because the shape of the beach is a bay bordered by hills and rocks, and behind the beach is directly connected to the forest, reducing the space for visitors, in contrast to other beaches such as Mustika Beach which has a longer coastline and land use around the coast wider. The response of the community to the development of Wedi Ireng Beach tourism object has a value of 20 which means it is quite supportive. The results of interviews with business actors in the field explained that the surrounding community agreed with the development of these tourism objects, but the differences in interests and objectives of the community with Perhutani as the responsible party of the area made the conflict which caused this beach to not develop.

\section{d. Accomodation}

Accommodation is an important element in tourism to support the needs of tourists who want to stay longer. Accommodation is calculated in a radius of $15 \mathrm{~km}$ from the object with regard to the number of rooms in the available lodging or hotel. The location of Wedi Ireng Beach which is included in a row of beaches in Pesanggaran District where there are other tourism objects that have been developed so that many people provide places to stay such as homestays and hotels. However, from the field data the number of available rooms is still low, namely 30-50 rooms, so it still needs to be added because in the assessment of development an element has a high value if a tourist object has more than 100 rooms. 


\section{e. Facilities and Infrastructure}

Adequate facilities and infrastructure will add to the advantages of a tourist attraction. The facilities and infrastructure available at Wedi Ireng Beach with a radius of 5-15 km have several sub-elements that fulfill such as public toilets, rest areas, and food/drink shops. However, other service facilities such as public transportation, health facilities such as hospitals and health centres, electricity networks do not yet exist because the main access to the beach is not yet available, as well as places of worship and parking areas. These facilities can be found at Mustika Beach, which is located on the east side of the Wedi Ireng beach.

\section{f. Availability of Clean Water}

The availability of clean water at Wedi Ireng Beach has a high enough value because it meets several sub-elements, including the volume of water, the distance of water sources with the location of objects $0-1 \mathrm{~km}$ and easy to obtain. Besides that, the taste of water is also tasteless so it is suitable for consumption and availability throughout the year. The use of water is not optimal, the facts found in the field, one of which is used for bath and washing purposes, but only using jerry cans taken from the nearest well by the manager there and the conditions of the toilets are also not feasible and not clean enough.

\section{Figure 1. Wedi Ireng Beach}

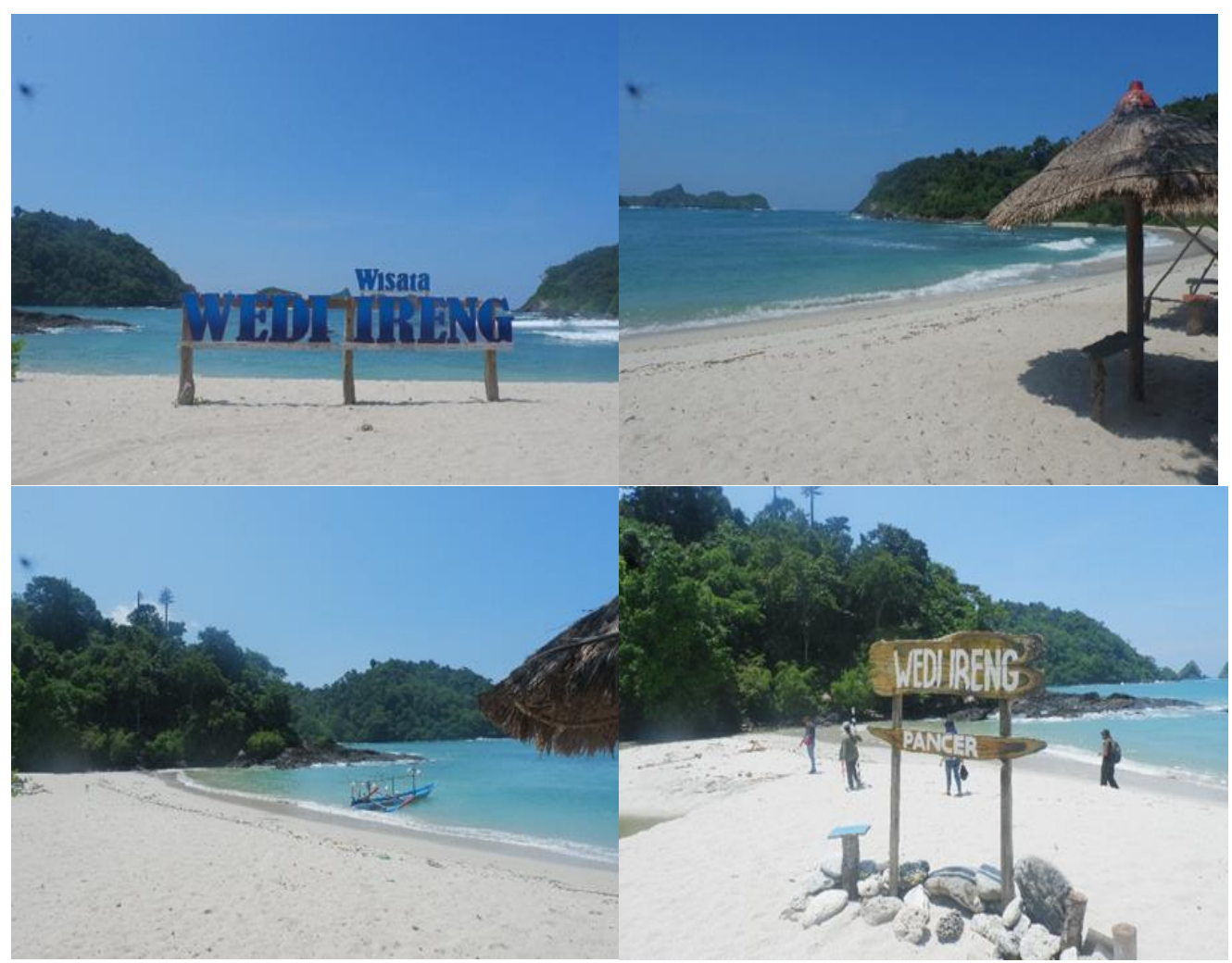




\subsection{Regional Carrying Capacity Analysis}

Carrying capacity is a basic concept that is developed for the management of a natural and sustainable environment, through a measure of its ability. It is necessary to study about the potential and environmental carrying capacity, so do not cause disruption the ecosystem and the tourism existing activities still comfort. Given the level of vulnerability and limited space for visitors, it is necessary to determine the carrying capacity of the region. The concept of carrying capacity is expected to be able to minimize or prevent damage to natural resources and the environment from the utilization efforts carried out. The Efforts to manage natural resources and environment in a sustainable manner can be carried out while paying attention to the welfare of the resource user community [15].

The natural environment, biologically diverse habitats, and indigenous culture of destination places are the key attractions for the tourists, and often they help create mass tourism. But tourism saturation ultimately causes damage to these key assets for tourism, and finally eventual loss of revenues arising from a collapse in tourism arrivals becomes permanent. To avoid this, tourism carrying capacity is often found to be discussed, homestays, calculated, and also implemented in a tourist destination, as every destination has its carrying capacity, beyond which it should not be developed and used for tourism activities [16].

The results of the calculation of the area (polygon) of the Wedi Ireng beach area using the GIS Arc can be seen that the area of the coast that can be used for beach recreation or sports tourism is $7,561 \mathrm{~m}^{2}$. According to the table of ecological potential and time prediction [13]), it is known that the ecological potential of visitors $(\mathrm{K})$ unit area for beach recreation or sports tourism is $50 \mathrm{~m} 2(\mathrm{Lt})$. Based on the results of interviews with visitors to the Wedi Ireng beach tourism object, it is known that the average time spent by visitors is 3 hours (Wp). The length of time the area provides for travelling in 1 day is 9 hours $(\mathrm{Wt})$. The results of calculations using the formula get the Regional Carrying Capacity (DDK) value of 454 people/day. This value is still in the safe category because the number of tourist visits in Wedi Ireng Beach in one day ranges from 40-110 people per day. So, for now, there are no serious problems that can later occur for damage to nature or the environment because the beach is still able to accommodate the number of tourists there.

\section{Conclusion}

The environmental carrying capacity in the area is not constant but dynamic, so the ability of a system can be increased or decreased. Sustainable development strategy tourism is necessary for the management of natural resources sustainability [17]. Wedi Ireng Beach as a whole has a feasibility level of 695 which means it is potential and feasible to be developed as tourism attraction object. Some things that support the development of Wedi Ireng beach tourism include the attraction and conditions around the coast in the form of bays with white sand, as well as many shady Ketapang trees found around the beach. The results of calculations using the carrying capacity formula according to Yulianda (2007)[13] , Carrying Capacity estimation of Wedi Ireng beach for tourism is 454 people per day, while the calculation of the value is still in the safe category because the number of tourist visits in Wedi Ireng Beach in one day ranged between 40-110 people every day. So for now there are no serious problems that can later occur for damage to nature or the environment because the beach is still able to accommodate the number of tourists there. 


\section{References}

[1] P. Hutan, "Pedoman Analisis Daerah Operasi Obyek dan Daya Tarik Wisata Alam (ADO-ODTWA)," Direktorat Jenderal Perlindungan Hutan dan Konserv. Alam. Bogor, 2003.

[2] "Badan Pusat Statistik. Statitik Pariwisata Jawa Timur 2017."

[3] Banyuwangi.kab.go.id., "Profil Kabupaten Banyuwangi 2018." .

[4] O. A. Yoeti, Pengantar Ilmu Pariwisata. Bandung: Angkasa, 2008.

[5] B. Faulkner, "Perkembangan Pariwisata Di Indonesia: Perspektif Gambaran Besar," Bandung ITB, 1997.

[6] I. N. Arida, Perencanaan Pariwisata Berkelanjutan Bali Timur: Memaknai Erupsi Gunung Agung. Tren Pariwisata Milenium: Diskursus dengan Alam, Bahasa, Sejarah dan Pasar. Denpasar: UDAYANA, 2017.

[7] K. P. dan E. K. R. Indonesia, "Rencana Strategis 2012- 2014," 2014.

[8] I. G. Pitana and P. G. Gayatri, Sosiologi Pariwisata: Kajian sosiologis terhadap struktur, sistem, dan dampak-dampak pariwisata. Andi, 2005.

[9] D. ALI, "PEMANFAATAN POTENSI SUMBERDAYA PANTAI SEBAGAI OBYEK WISATA DAN TINGKAT KESEJAHTERAAN MASYARAKAT SEKITAR LOICASI WISATA (Shull Kamm di Kawasan Wisata Pantai Kartini Jepara) COASTEL RESOURCES AS A TOURISM SITE AND INCR. EASING SOCIAL WELFARE FOR THE PEOPLE NEARBY." Program Pascasarjana Universitas Diponegoro, 2004.

[10] I. Rizk and M. Rashed, "Monitoring urban growth and land use change detection with GIS and remote sensing techniques in Daqahlia governorate Egypt," Int. J. Sustain. Built Environ., vol. 4, no. 1, pp. 117-124, 2015.

[11] J. Damanik, Pariwisata Indonesia Antara Peluang dan Tantangan. Yogyakarta: Pustaka Pelajar, 2013.

[12] K. dan S. L. Y. Denzin, N, Handbook of qualitative research. Yogyakarta: Dinas Pariwisata dan kebudayaan Kabupaten Malang, 2009.

[13] F. Yulianda, "Ekowisata Bahari Sebagai Alternatif Pemanfaatan Sumberdaya Pesisir Berbasis Konservasi.," Makal. Semin. Sains 21 Februari 2007, 2007.

[14] L. S. M. Gunawan, M. P., Kantor Menteri Negara Lingkungan Hidup: Proyek Agenda 21 Sektoral, United Nation Development Program (UNDP); Indonesia. 2000. Agenda Pariwisata Untuk Pengembangan Kualitas Hidup Secara Berkelanjutan. Proyek Agenda 21 Sektoral,. Jakarta: Menteri Negara Lingkungan Hidup dengan UNDP, 2000.

[15] H. P. Nugraha, A. Indarjo, and M. Helmi, "Studi kesesuaian dan daya dukung kawasan untuk rekreasi pantai di Pantai Panjang Kota Bengkulu," J. Mar. Res., vol. 2, no. 2, pp. 130-139, 2013.

[16] M. K. Hasan, Syed Rasidul, Hassan, Tourist-Group Consideration in Tourism Carrying Capacity Assessment: a New Approach for the Saint Martin's Island. Bangladesh, 2014.

[17] A. M. Aryasa, A. N. Bambang, and F. Muhammad, "The study of environmental carrying capacity for sustainable tourism in Telaga Warna Telaga Pengilon Nature Park, Dieng Plateu, Central Java," in IOP Conference Series: Earth and Environmental Science, 2017, vol. 70, no. 1, p. 12003. 